\title{
HUBUNGAN ANTARA DIKLAT DAN KOMPENSASI DENGAN PENINGKATAN KINERJA GURU PADA SEKOLAH DASAR NEGERI DI KOTA SOLOK
}

\author{
Arianto Tandika \\ Guru Madrasah Tsanawiyah Negeri 4 Solok \\ Korespondensi: Tembok Kacang Kecamatan X Koto Singkarak Kabupaten Solok \\ e-mail: arianto.tandika@gmail.com
}

\begin{abstract}
Many factors have correlation with teacher's performance, likes training and compensation. The teacher is not optimal in following training proses and compensation for teacher is not maximum yet also has effects to teacher's performance. The teacher as spearbead of education in learning process at school, so the teacher's quality and standard of life should be improved and developed according to the present and the future life. The research has purpose to know the correlation training and compensation with teacher's performance at state elementary school in Solok City. The research is quantitative research with correlational approach, in collecting data on research question. The technic collecting data is close questioner. The result is analyzed by use quantitative approach and use frequency table tools also statistic test by use SPSS program. Based on the result of data analysis there is a correlation between training and compensation with teacher's performance has meaning to correlation has found 0.654 with references to the degree of relation belonging a strong correlation, therefore the bypothesis in this research is acceptable:
\end{abstract}

Keywords: Training, Compensation, Teacher Performance

\section{PENDAHULAN}

Tujuan pendidikan nasional adalah untuk mencerdaskan kehidupan bangsa dan mengembangkan manusia Indonesia seutuhnya, yaitu yang beriman, bertakwa terhadap Tuhan Yang Maha Esa, berbudi pekerti luhur, memiliki pengetahuan dan keterampilan, sehat jasmani dan rohani, berkepribadian yang mantap dan mandiri, serta bertanggung jawab. Dalam rumusan Undang-Undang ini juga membutuhkan penanganan yang serius, cermat, komprehensif, strategis dan bertanggung jawab. Untuk menghasilkan SDM seperti tujuan pendidikan di atas.

Tiga syarat utama yang harus diperhatikan dalam membangun pendidikan agar dapat berkontribusi terhadap berhasilnya sumber daya manusia yang berkualitas, meliputi: 1) sarana gedung, 2) buku yang berkualitas, 3) guru dan tenaga kependidikan yang profesional (Mulyasa, 2008: 3). Dari tiga faktor tersebut, guru merupakan salah satu faktor penentu dalam peningkatan kualitas SDM pada dunia pendidikan. Untuk itu diharapkan guru memiliki beberapa kompetensi yang akan digunakan dalam melaksanakan tugasnya sebagai seorang pendidik. Hal ini sesuai dengan Peraturan Menteri Pendidikan Nasional Republik Indonesia Nomor 16 Tahun 2007 tentang Standar Kualifikasi Akademik dan Kompetensi Guru dijelaskan bahwa standar kompetensi guru dikem- 
bangkan secara utuh dari empat kompetensi utama, yaitu: kompetensi pedagogik, kepribadian, sosial, profesional.

Sejalan dengan pendapat Ranupandojo dan Husnan (1997: 77) mengatakan bahwa pendidikan merupakan suatu kegiatan untuk meningkatkan pengetahuan umum seseorang termasuk di dalamnya peningkatan penguasaan teori dan keterampilan memutuskan terhadap persoalan-persoalan yang menyangkut kegiatan mencapai tujuan. Sedangkan pelatihan membantu karyawan dalam memahami suatu pengetahuan praktis dan penerapannya, guna meningkatkan keterampilan, kecakapan dan sikap yang diperlukan oleh organisasi dalam usaha mencapai tujuannya.

Adapun salah satu upaya pemerintah dalam peningkatan kompetensi guru adalah melalui diklat, disamping itu faktor-faktor lain seperti: faktor finansial, fisik, sosial, psikologis juga memegang peranan yang sangat menentukan. Faktor finansial berhubungan dengan jaminan serta kesejahteraan guru yang meliputi gaji, jaminan sosial, promosi jabatan dan lain-lain. Sedangkan faktor fisik merupakan indikator yang berhubungan dengan jenis pekerjaan, pengaturan waktu kerja dan istirahat, perlengkapan kerja, keadaan suhu dan ruangan, penerangan, pertukaran udara, kondisi kesehatan dan umur guru. Faktor sosial atau faktor yang berhubungan dengan interaksi sosial sesama guru, kepala sekolah maupun lingkungan sekitar. Terakhir faktor psikologis yang mencakup minat, ketentraman dalam bekerja, sikap terhadap kerja, bakat dan keterampilan.

Keseluruhan faktor di atas memberikan warna kepada kinerja guru khususnya faktor kemampuan mengajar maupun pengembangan profesi, sehubungan dengan hal tersebut diperlukan upaya secara sistematik untuk mengurangi pengaruh negatif dan memberi pengaruh positif yang terencana melalui diklat, karena menurut Peraturan Pemerintah nomor 101 tahun 2000 dalam Lembaga Administrasi Negara (2009), menjelaskan bahwa diklat bagi guru / ASN berguna untuk

1. Meningkatkan pengetahuan, keahlian, keterampilan dan sikap untuk melaksanakan tugas jabatan secara profesional dengan dilandasi kepribadian dan etika PNS (Pegawai Negeri Sipil) sesuai dengan kebutuhan instansinya.

2. Menciptakan aparatur yang mampu berperan sebagai pembantu dan perekat persatuan dan kesatuan bangsa.

3. Memantapkan sikap dan semangat pengabdian yang berorientasi pada pelayanan, pengayoman, dan pemberdayaan masyarakat.

4. Menciptakan kesamaan visi dan dinamika pola pikir dalam melaksanakan tugas pemerintahan umum dan pembangunan demi terwujudnya kepemerintahan yang baik.

Pembinaan guru/ASN melalui diklat diharapkan dapat meningkatkan kinerja sesuai dengan tugas pokok dan fungsinya sebagai penyedia layanan (Service provider), dan dapat mengembangkan kemampuan mengajar dan pengembangan profesi.

Selain diklat, kompensasi yang diterima guru juga berperan pada peningkatan kinerjanya sebagai pendidik. Kompensasi seterusnya dapat dibagi menjadi dua yaitu : kompensasi finansial dan kompensasi non finansial. Kompensasi finansial merupakan pembayaran oleh suatu organisasi atau madrasah kepada guru dalam bentuk finansial baik secara langsung maupun tidak langsung sebagai balas jasa atas kontribusi- 
nya kepada organisasi. Sedangkan kompensasi non finansial merupakan bentuk kompensasi yang diberikan kepada karyawan selain dalam bentuk uang, seperti pujian, menghargai diri sendiri, dan pengakuan yang dapat mempengaruhi motivasi kerja karyawan, produktivitas, dan kinerja.

Hal ini senada dengan Samsudin (dalam Kadarisman, 2012: 49) menyatakan bahwa kompensasi mengandung arti yang lebih luas daripada upah atau gaji. Upah atau gaji lebih menekankan pada balas jasa yang bersifat finansial, sedangkan kompensasi mencakup balas jasa finansial maupun non finansial. Kompensasi merupakan pemberian balas jasa, baik secara langsung berupa uang (finansial) maupun tidak langsung berupa penghargaan (non finansial

Berdasarkan observasi dan wawancara yang penulis lakukan di beberapa Sekolah Dasar Negeri yang ada di Kota Solok diperoleh informasi sebagai berikut:

1. Gaji yang diterima guru honor belum membantu untuk kesejahteraannya dan adanya keterlambatan dalam pembayarannya.

2. Adanya beberapa guru yang kurang semangat dalam menyelesaikan tugas yang diberikan padanya, dan cenderung terlambat dari waktu yang telah ditentukan, seperti pengumpulan perangkat pembelajaran dan administrasi lainnya.

3. Minimnya fasilitas yang ada disekolah, seperti pengadaan buku-buku paket, media dan lain-lain.

4. Proporsi diklat untuk setiap guru belum merata sehingga masih ada guru yang belum mengikuti diklat dalam jabatan

5. Diklat yang diikuti guru tidak berkesinambungan atau terputus
6. Berkurangnya anggaran untuk sekolah dalam pelaksanaan kegiatan-kegiatan ekstrakurikuler, padahal dengan kegiatan tersebut dapat membantu peserta didik untuk meningkatkan kompetensinya.

7. Belum maksimalnya anggaran yang dialokasikan untuk pembuatan bahan ajar guru seperti pembuatan LKS (Lembar Kegiatan Siswa) untuk keperluan belajar peserta didik

Berdasarkan hal tersebut menurut peneliti kajian tentang hubungan antara diklat dan kompensasi dengan peningkatan kinerja guru pada Sekolah Dasar Negeri di Kota Solok penting untuk dikaji.

\section{METODE PENEUTAN}

Penelitian ini dilakukan dengan metode kuantitatif yang difokuskan pada tiga variabel yaitu Diklat, Kompensasi, dan Peningkatan Kinerja. Penelitian ini bertujuan untuk melihat hubungan antara variabel di atas, menguji hipotesis yang telah diajukan dan membahas temuan penelitian hanya sebatas varibel itu sendiri.

Metode kuantitatif yang digunakan dalam penelitian ini adalah metode korelasi. Hubungan antara variabel dilihat secara korelasional. Selanjutnya dilihat pula hubungan sebab akibat dari masing-masing variabel tersebut.

Populasi dari penelitian ini adalah seluruh guru yang ada di Sekolah Dasar Negeri di Kota Solok, jumlah guru pada Sekolah Dasar Negeri di Kota Solok yang menjadi sampel adalah sebanyak 72 orang.

Sampel penelitian ini akan diambil dengan menggunakan teknik Simple Random Sampling. Teknik ini memberikan peluang yang sama kepada semua anggota populasi 
untuk diambil menjadi sampel yang respresentatif yang dapat menggambarkan karakteristik populasi. Pemilihan sampel dilakukan melalui dengan cara undian dilakukan dengan memberi nomor-nomor pada seluruh anggota populasi, lalu secara acak dipilih nomor-nomor sesuai dengan banyaknya jumlah sampel yang dibutuhkan (Sugiyono, 2015:64).

Data penelitian diolah dan dianalisis dengan menggunakan Teknik Korelasi Product Moment dan Teknik Korelasi Ganda. Analisis data dilakukan dengan bantuan program komputer SPSS Versi 22.0 For Windows (Santoso, 2016: 333).

\section{HASIL PENEUTIANDAN PEMBAHASAN}

\section{Deskripsi Data Penelitian}

Data pada penelitian ini diperoleh dengan menyebarkan angket kepada responden yang terdiri atas sepuluh Sekolah Dasar Negeri mewakili dari empat puluh Sekolah Dasar Negeri di Kota Solok. Pendistribusian angket dilakukan dengan mendatangi secara langsung SDN yang menjadi lokasi pengambilan sampel dan membagikannya kepada responden, angket yang disebarkan terdiri dari 3 variabel yaitu variabel diklat, kompensasi dan kinerja. Proses pendistribusian hingga pengumpulan data dilakukan selama 3 minggu yaitu dari tanggal 12 Agustus 2016 sampai dengan 31 Agustus 2016.

Dalam angket penelitian ini terdapat bagian pernyataan-pernyataan dalam bentuk skala likert untuk masing-masing variabel, baik itu variabel dependen maupun independen yang digunakan dalam penelitian ini. Pernyataan-pernyataan tersebut berhubungan dengan diklat, kompensasi dan kinerja. Dalam angket tersebut terdapat 95 pernyataan yang terbagi-bagi yakni 25 pernyataan yang digunakan untuk mewakili variabel diklat, 25 pernyataan yang digunakan untuk mewakili variabel kompensasi dan 45 pernyataan yang digunakan untuk mewakili variabel kinerja. Pernyataan tersebut kiranya dapat mewakili setiap variabel baik variabel dependen maupun variabel independen yang digunakan dalam penelitian ini.

Untuk mengetahui hubungan antara diklat dan kompensasi dengan peningkatan kinerja guru pada Sekolah Dasar Negeri di Kota Solok berdasarkan angket yang dibagikan kepada 72 orang responden yaitu guru-guru yang mengajar pada Sekolah Dasar Negeri di Kota Solok, maka pertamatama dihitung jumlah skor ideal, atau skor kriterium. Skor ideal adalah apabila semua responden menjawab angka 5. Jumlah skor ideal untuk hubungan antara diklat dan kompensasi dengan peningkatan kinerja guru yang diharapkan adalah $5 \times 95 \times 72=$ 34.200 ( $5=$ skor tertinggi, $95=$ jumlah butir item, $72=$ jumlah responden). Berdasarkan data yang terkumpul jumlah skor $=28.812$. dengan demikian hubungan antara diklat dan kompensasi dengan peningkatan kinerja guru $=28.812: 34.200$ $=84,24 \%$ (skor tertinggi 100). (Sugiyono, Metode Penelitian Manajemen, 2015: 640)

\section{Diklat $\left(X_{1}\right)$}

Skor tertinggi tiap butir instrumen $=5$. Jumlah butir instrumen $=25$, jumlah responden $=72$. Dengan demikian skor ideal $=5 \times 25 \times 72=9.000$. selanjutnya skor data yang diperoleh dari 72 responden $=7.387$. Dengan demikian nilai persentase variabel diklat menurut responden $=7.387$ : $9.000=0,8207$ atau $82,07 \%$. Jadi diklat yang telah diikuti oleh guru telah mencapai 
$82,07 \%$ dari yang diharapkan. Hal ini berarti diklat yang telah diikuti oleh guru pada SD Negeri di Kota Solok termasuk dalam kategori baik.

Dari data diklat yang penulis uraikan dapat dikatakan bahwa diklat bisa menambah wawasan dan meningkatkan profesionalisme guru untuk berkreativitas menunjang profesi yang dijalankan oleh seorang guru, menambah keahlian dan pengetahuan, sehingga di dalam melaksanakan tugas-tugasnya dapat lebih efisien dan produktif.

\section{Kompensasi}

Skor tertinggi tiap butir instrumen $=5$. Jumlah butir instrumen $=25$, jumlah responden $=72$. Dengan demikian skor ideal $=5 \times 25 \times 72=9.000$. selanjutnya skor data yang diperoleh dari 72 responden $=7.232$. Dengan demikian nilai persentase variabel kompensasi menurut responden = $7.232: 9.000=0,8035$ atau $80,35 \%$.. Hal ini berarti kompensasi yang telah diterima oleh guru pada SD Negeri di Kota Solok termasuk dalam kategori baik, berarti sebagian besar tanggapan responden pada skor 4 dan 5, dimana rata-rata tertinggi pada butir 1 mengenai hak yang diterima berupa gaji tiap bulannya oleh guru-guru SDN di Kota Solok tepat pada waktunya, sedangkan rata-rata yang terendah pada butir 20 yaitu kurangnya penghargaan berupa pujian yang diterima oleh guru SDN di Kota Solok atas prestasi kerja yang telah dicapai.

Dari data kompensasi yang penulis uraikan dapat dikatakan bahwa kompensasi yang diterima guru setiap bulannya dapat menunjang kesejahteraan guru itu sendiri, dilain sisi tunjangan yang memadai serta jaminan keselamatan dalam bekerja berupa asuransi kesehatan sebagai bagian motivasi untuk guru agar tercapai kineja yang lebih tinggi. Kebutuhan guru bukan hanya berupa gaji dalam bentuk uang tetapi penghargaan dari prestasi kerja yang mereka peroleh memberi warna tersendiri dalam meningkatkan kinerja atau prestasi kerjanya dalam hal ini akan berdampak positif terhadap peningkatan kinerja guru selaku tenaga pendidik.

\section{Kinerja Guru SD Negeri di Kota Solok}

Skor tertinggi tiap butir instrumen $=5$. Jumlah butir instrumen $=45$, jumlah responden $=72$. Dengan demikian skor ideal $=5 \times 45 \times 72=16.200$. selanjutnya skor data yang diperoleh dari 72 responden $=14.193$. Dengan demikian nilai persentase variabel kompensasi menurut responden $=$ $14.193: 16.200=0,8761$ atau $87,61 \%$.. Hal ini berarti kinerja guru pada SD Negeri di Kota Solok termasuk dalam kategori baik.

Perencanaan pembelajaran, pelaksanaan pembelajaran, dan evaluasi pembelajaran memberi arti pada kinerja dan usaha yang perlu dilakukan bersama-sama oleh warga sekolah terutama guru. Adapun tanggapan responden terhadap data kinerja akan dijabarkan berdasarkan skala Likert, sebagian besar responden memberikan tanggapan pada skor 4 dan 5 dengan melihat rata-rata pada indikator perencanaan pembelajaran $(4,59)$, indikator pelaksanaan pembelajaran $(4,47)$, indikator evaluasi pembelajaran $(4,31)$, sehingga skor rata-rata menunjukkan angka 4,47, hal ini bisa diinterpretasikan bahwa guru-guru SDN di Kota Solok telah mempersiapkan rancangan pembelajaran pada awal tahun pelajaran, telah melaksanakan proses pembelajaran dengan sebaik mungkin, dan telah melakukan evaluasi pembelajaran dengan benar. Hali ini merupakan capaian dari proses kinerja yang 
telah dilakukan oleh guru di SDN Kecamatan Tanjung Harapan Kota Solok, kinerja/hasil kerja yang dicapai oleh guru dalam kurun waktu tertentu sebagai wujud tanggung jawab terhadap tugas dan kewajiban yang dibebankan kepadanya ini dibuktikan dengan data secara empris bahwa kinerja guru di SDN Kecamatan Tanjung Harapan Kota Solok pada klasifikasi baik.

\section{Uji Prasyarat Analisis}

Uji prasyarat analisis dalam penelitian ini dilakukan sebelum uji hipotesis. Uji prasyarat analisis yang dilakukan adalah uji normalitas dan uji linearitas.

\section{Uji Normalitas}

Uji normalitas dilakukan untuk mengetahui apakah nilai residual berdistribusi normal atau tidak. Penentuan normal atau tidaknya distribusi data dilakukan pengujian dengan menggunakan statistik Kolmogorov-Smirnov. Uji normalitas kolmogorov smirnov merupakan bagian dari uji asumsi klasik. Model regresi yang baik adalah memiliki nilai residual yang berdistribusi normal. Dasar pengambilan keputusan : (a) jika nilai Signifikansi $>0,05$, maka nilai residual berdistribusi normal. (b) jika nilai Signifikansi $<0,05$, maka nilai residual tidak berdistribusi normal. Perhitungan dengan bantuan program SPSS Statistic 22 for Windows. Berdasarkan hasil uji normalitas diketahui nilai signifikansi 0,467 $>0,05$, maka dapat disimpulkan bahwa nilai residual berdistribusi normal.

\section{Uji Linearitas}

Uji linearitas dilakukan untuk mengetahui linearitas hubungan variabel diklat $\left(\mathrm{X}_{1}\right)$, kompensasi $\left(\mathrm{X}_{2}\right)$ dengan kinerja guru (Y) pada SD Negeri Kecamatan Tanjung Harapan Kota Solok. Lineartias dilakukan dengan menggunakan uji $F$. Hubungan antara variabel bebas dengan variabel terikat linier apabila nilai $F_{\text {hitung }}$ lebih kecil atau sama dengan $\mathrm{F}_{\text {tabel }}\left(\mathrm{F}_{\text {hitung }}<\mathrm{F}_{\text {tabel }}\right)$ pada taraf signifikansi 5\%. Uji $\mathrm{F}$ dalam penelitian ini merupakan harga koefisien $\mathrm{Fa}$ pada baris Deviation from linearity yang tercantum dalam tabel ANOVA pada output penghitungan dengan bantuan program SPSS Statistic 22 for Windows. Dasar pengambilan keputusan: (a) jika nilai signifikansi deviation from linearity $>0,05$, maka terdapat hubungan yang linear antara variabel bebas dengan variabel terikat, (b) jika nilai signifikansi deviation from linearity < 0,05, maka tidak terdapat hubungan yang linear antara variabel bebas dengan variabel terikat.

Berdasarkan uji linearitas variabel diklat $\left(\mathrm{X}_{1}\right)$ dengan kinerja guru $(\mathrm{Y})$ menunjukkan koefisien $F_{\text {hitung }}$ sebesar 0,867 lebih kecil dari $\mathrm{F}_{\text {tabel }}$ sebesar 1,74. Pada uji linearitas variabel Kompensasi $\left(\mathrm{X}_{2}\right)$ dengan kinerja guru $(\mathrm{Y})$ menunjukkan koefisien $F_{\text {hitung }}$ sebesar 0,998 lebih kecil dari $F_{\text {tabel }}$ sebesar 1,75. Dengan demikian, variabel diklat dan kompensasi mempunyai hubungan linear dengan kinerja Guru. Berdasarkan penghitungan tersebut, korelasi masing-masing variabel bebas dengan variabel terikat adalah linear, sehingga analisis korelasi dapat dilanjutkan.

\section{Pengujian Hipotesis}

\section{Hubungan Diklat dengan Kinerja Guru}

Dalam penelitian ini hipotesis yang pertama diajukan adalah hubungan antara diklat dengan kinerja guru. Dasar pengambilan keputusan adalah jika nilai signifikansi kurang dari 0,05, maka 
berkorelasi, dan jika nilai signifikansi lebih dari 0,05, maka tidak berkorelasi.

Dari hasil analisis korelasi product moment mengenai hubungan diklat $\left(\mathrm{X}_{1}\right)$ dengan kinerja guru (Y) diperoleh nilai korelasi signifikansi sebesar 0,000. Artinya nilai signifikansi dari hubungan diklat dengan kinerja adalah berkorelasi karena nilai sig. diklat dengan Kinerja > 0,05.

Guna mengetahui tingkat keberartian/signifikansi dan hasil korelasi antara diklat dengan kinerja guru, berdasarkan tabel tersebut diperoleh nilai pearson correlation sebesar 0,556. Jadi ada korelasi positif antara diklat dengan kinerja guru. Untuk memberikan penafsiran terhadap korelasi yang ditemukan sebesar 0,556 dapat berpedoman pada ketentuan koefisien korelasi yang ditemukan tergolong korelasi sedang.

\section{Hubungan Kompensasi dengan Kinerja Guru}

Dalam penelitian ini hipotesis yang kedua diajukan adalah Hubungan antara Kompensasi dengan Kinerja Guru. Dasar pengambilan keputusan adalah jika nilai signifikansi kurang dari 0,05, maka kompensasi dan kinerja guru berkorelasi, dan jika nilai signifikansi lebih dari 0,05, maka dikatakan tidak berkorelasi

Dari hasil analisis korelasi product moment mengenai hubungan kompensasi $\left(\mathrm{X}_{2}\right)$ dengan kinerja guru $(\mathrm{Y})$ diperoleh nilai korelasi signifikansi sebesar 0,000. Artinya nilai signifikansi dari hubungan kompensasi dengan kinerja adalah berkorelasi karena nilai sig. kompensasi dengan kinerja $>0,05$.

Guna mengetahui tingkat keberartian/signifikansi dan hasil korelasi antara kompensasi dengan kinerja guru, berdasarkan tabel tersebut diperoleh nilai pearson correlation sebesar 0,628. Ini berarti korelasi positif antara kompensasi dengan kinerja guru. Untuk memberikan penafsiran terhadap korelasi yang ditemukan sebesar 0,628 dengan merujuk pada pedoman tingkat hubungan (tabel 4.10.) tergolong korelasi kuat.

\section{Hubungan Diklat dan Kompensasi dengan Kinerja Guru}

Pada hipotesis ketiga dilakukan uji korelasi ganda,yaitu hubungan antara diklat dan kompensasi dengan kinerja. Angka yang menunjukkan arah dan besar kuatnya hubungan antara dua variabel bebas dengan satu variabel terikat disebut koefisien korelasi ganda,dan biasa disimbokan R.

Pengujian hipotesis korelasi ganda menggunakan uji $\mathrm{F}$ (tabel distribusi F) dengan derajat kebebasan (dk). Dasar pengambilan keputusan adalah jika nilai $\mathrm{F}$ hitung atau sig. $F$ change $<0,05$, maka variabel bebas dengan variabel berkorelasi, sebaliknya jika nilai sig. $F$ change $>0,05$, maka tidak berkorelasi

Dari hasil analisis korelasi ganda mengenai hubungan antara diklat $\left(\mathrm{X}_{1}\right)$ dan kompensasi $\left(\mathrm{X}_{2}\right)$ dengan kinerja guru $(\mathrm{Y})$ diperoleh nilai korelasi signifikansi diketahui sebesar 0,000. Artinya nilai signifikansi hubungan antara diklat dan kompensasi dengan kinerja guru adalah berkorelasi karena nilai sig. F change $>0,05$.

Guna mengetahui tingkat keberartian/signifikansi dan hasil korelasi antara diklat dan kompensasi dengan kinerja guru, berdasarkan tabel tersebut diperoleh nilai $\mathrm{R}$ sebesar 0,654. Hal ini menggambarkan ada korelasi positif antara diklat dan kompensasi dengan kinerja guru. Untuk memberikan penafsiran terhadap korelasi yang ditemukan sebesar 0,654 dengan merujuk 
pada pedoman tingkat hubungan (tabel 4.18.) kategori tergolong korelasi kuat.

\section{Pembahasan}

Berdasarkan penelitian yang telah dilakukan, maka peneliti akan membahas satu persatu tentang hasil penelitian terhadap ketiga variabel dalam penelitian ini yaitu variabel diklat, kompensasi dan kinerja guru.

\section{Diklat}

Dari hubungan diklat dengan kinerja guru didapatkan informasi bahwa terdapat hubungan yang signifikan antara diklat dan kinerja guru dengan taraf signifikansi sedang. Hal tersebut dilengkapi dengan data hasil analisis statistik deskriptif yang diperoleh dari data diklat adalah dengan rata-rata 104,60 yang terletak pada interval 97,02 - 112,18 dengan kriteria sedang.

Dari data yang diperoleh menunjukkan bahwa diklat yang diikuti guru SDN di Kota Solok masih heterogen yang ditunjang oleh nilai standar deviasi yang cukup besar yaitu 7,584 hal ini dapat diartikan menjadi beberapa penafsiran :

1. Ada guru yang belum pernah mengikuti diklat

2. Ada guru yang sudah beberapa kali mengikuti diklat

3. Ada guru yang mengikut diklat secara berkesinambungan

Menurut Siagian mengatakan bahwa Salah satu cara dalam meningkatkan kinerja aparatur sebagai upaya dalam mengembangkan sumber daya manusia ialah melalui pendidikan dan pelatihan atau dikenal sebagai diklat. (Siagian, 1995: 178)

Pada pelaksanaan diklat ada beberapa faktor yang menimbulkan berbagai macam hambatan terhadap ketidakberhasilan diklat, menurut hemat peneliti melihat kondisi di lapangan ada beberapa hambatan : Pertama, diklat masih dipandang hanya formalitas karena tidak didasari dengan analisis kebutuhan diklat, sehingga terkadang peserta yang mengikuti diklat bukan peserta yang membutuhkan peningkatan kompetensi, kadang kala hanya dipandang sebagai peningkatan kesejahteraan guru karena melakukan perjalanan dinas untuk mengikuti diklat tersebut. Dalam banyak kasus, peserta yang diharapkan mengikuti tahap selanjutnya dalam skema diklat, tidak ikut kembali dan diganti oleh orang lain dengan berbagai alasan. Hal ini sesuai dengan pendapat Handoko menyatakan bahwa pelatihan dimksudkan untuk menguasai berbagai keterampilan dan teknik pelaksanaan kerja tertentu terinci dan rutin. (Handoko, 1995: 104)

Kedua, Pelaksanaan diklat masih belum mempunyai standar pelaksanaan. Standar pelaksanaan tersebut meliputi kompetensi, tenaga pengajar, dan sarana prasarana, standar pelaksanaan sangat penting dilakukan untuk penyeragaman pelaksanaan dan menjaga kualitas diklat, karena tidak terstandar maka pelaksanaan diklat kadang disesuaikan dengan kondisi keuangan instansi tanpa memperhatikan sasaran yang akan dicapai dalam pelaksanaan diklat tersebut. Hal ini sesuai dengan pendapat Wijaya menyatakan bahwa pendidikan dan pelatihan akan memberikan bantuan pada masa yang akan datang dengan jalan pengembangan pola pikir dan bertindak, terampil berpengetahuan dan mempunyai sikap serta pengertian yang tepat untuk pelaksanaan pekerjaan. (Wijaya, 1995: 5)

Ketiga, tidak ada output atau parameter keberhasilan diklat yang terukur, sehingga 
tingkat keberhasilan pelaksanaan diklat sulit diukur, dengan tidak terdapat parameter yang jelas berimbas pada saat setelah dilakukan diklat cenderung tidak melaksanakan tindak lanjut. Hal senada dikemukakan Ranupandojo bahwa pelatihan dilakukan untuk memperbaiki kemampuan kerja seseorang dalam kaitannya dengan aktifitas ekonomi, dan membuat keterampilan, kecakapan dan sikap yang diperlukan oleh organisasi dalam usaha mencapai tujuan. (Ranupandojo, 1986:6)

Keempat, tidak ada pengawasan dan pengendalian lulusan diklat, sehingga pengembangan guru yang mengikuti diklat sulit di monitor, bahkan cenderung setelah dilakukan diklat tidak dilakukan evaluasi terhadap peserta. Pada umumnya orang beranggapan bahwa evaluasi program pelatihan diadakan pada akhir pelaksanaan diklat, anggapan yang demikian adalah kurang tepat, karena evaluasi merupakan salah satu mata rantai dalam sistem diklat yang jika dilihat dari waktu pelaksanaannya kegiatan penilaian dapat berada di awal proses perencanaan, di tengah proses pelaksanaan dan pada akhir penyelenggaraan diklat dan pasca kegiatan diklat. Penilaian pasca diklat bertujuan untuk mengetahui perubahan kinerja peserta setelah kembali ke tempat kerjanya masing-masing. Hal ini senada dengan Notoatmodjo bahwa evaluasi terhadap hasil, mencakup sejauh mana materi diberikan itu dapat diserap dan dikuasai oleh peserta diklat, lebih jauh lagi apakah ada peningkatan kemampuan, keterampilan, pengetahuan, sikap dari para peserta diklat (Notoatmodjo, 2003: 23)

\section{Kompensasi}

Kebijakan kompensasi merupakan kebijakan yang penting dan strategis karena hal ini langsung berhubungan dengan peningkatan semangat kerja, kinerja guru pada suatu lembaga pendidikan. Adapun indikator kompensasi adalah:
a) Gaji atau upah
b) Tunjangan
c) Penghargaan

Berdasarkan hasil analisis deskripsi data tentang tingkat pencapaian indikator kompensasi hasilnya sebagai berikut:

Menurut hasil penelitian yang penulis lakukan kondisi aktual variabel kompensasi secara umum kondisinya tergolong baik (81,68\%). Dengan demikian, secara umum pemberian kompensasi baik dalam (1) gaji atau upah yang diterima sudah sesuai dengan profesi yang dijalankan, (2) penerimaan tunjangan yang cukup memadai, (3) rasa penghargaan yang diterima oleh guru

Setelah dilakukan pengkajian mendalam melalui proses analisis di atas, maka diyakini bahwa hipotesis penelitian yang menyatakan "hubungan kompensasi dengan kinerja guru" dapat diterima dan telah telah teruji pada taraf kepercayaan 95\%. Selanjutnya dapat diinterpretasikan bahwa kompensasi memiliki korelasi positif dan signifikan dengan kinerja guru sebesar 39,44\%. Hal ini menunjukkan bahwa $39,44 \%$ ketercapaian kinerja guru ditentukan oleh layanan kompensasi yang diterimanya. Hal ini sesuai dengan pendapat (Notoatmodjo, 2003: 153) yang menyatakan bahwa segala sesuatu yang diterima oleh karyawan sebagai balas jasa untuk kerja mereka.

Guru dalam melaksanakan tugas untuk mencapai kinerja yang baik seperti merencanakan program pembelajaran, melakukan proses pembelajaran bersama peserta didik, mengevaluasi kegiatan di akhir pembelajaran sangat erat hubungan- 
nya dengan kompensasi yang diterima oleh guru tersebut. Hal ini sejalan dengan pendapat Mutiara Pangabean dalam subekhi menyatakan bahwa setiap bentuk penghargaan yang diberikan karyawan sebagai balas jasa atas kontibusi yang mereka berikan kepada organisasi. (Subekhi, 2012: 176)

Menurut hemat peneliti melihat kondisi di lapangan sebagian besar masyarakat menganggap kompensasi sangat penting, sebab besarnya kompensasi bagi mereka mencerminkan ukuran nilai karya mereka, keluarga dan masyarakat. Tingkat kompensasi menentukan skala kehidupan, menunjukkan status, martabat, dan harga diri.

\section{Kinerja Guru}

Kinerja guru merupakan proses pembelajaran sebagai upaya mengembangkan kegiatan yang ada menjadi kegiatan yang lebih baik, sehingga tujuan pendidikan yang telah ditetapkan dicapai dengan baik melalui suatu kegiatan pembelajaran yang dilaksanakan oleh guru sesuai dengan target dan tujuan.

Dari hasil penelitian yang penulis lakukan terhadap kinerja guru, kondisi aktualnya secara umum kondisinya tergolong cukup. Ditemukan bahwa tingkat pencapaian skor keseluruhan kinerja guru termasuk sedang. Hasil ini menunjukkan bahwa kinerja guru belum optimal sesuai dengan yang diharapkan. Hasil statistik deskriptif diperoleh rata-rata 201,24 yang terletak pada interval 191,87 - 210,61 dengan kriteria sedang, dapat dinyatakan bahwa kinerja guru SD Negeri di Kota Solok adalah kategori sedang.

Ukuran kinerja guru terlihat dari rasa tanggung jawabnya menjalankan amanah.
Profesi yang diembannya, rasa tanggung jawab moral dipundaknya. Semua itu akan terlihat kepada aktivitas dan kreatifitas di dalam menjalankan tugas profesinya di dalam kelas, maupun dalam kehidupan bersosial kemasyarakatan. Hal ini sesuai dengan pendapat Rusyan dkk (2000: 17) menyatakan kinerja guru adalah melaksanakan proses pembelajaran baik dilakukan di dalam kelas maupun di luar kelas di samping mengerjakan kegiatan-kegiatan lainnya seperti mengerjakan administrasi sekolah dan administrasi pembelajaran, melaksanakan bimbingan dan layanan pada para siswa, serta melaksanakan penilaian.

\section{Hubungan antara Diklat dan Kompensasi dengan Kinerja Guru}

Berdasarkan hasil penelitian dan pengujian hipotesis di atas, terbukti bahwa ada hubungan yang positif dan sifnifikan pendidikan dan pelatihan, kompensasi dengan kinerja guru sedang dan kuat secara parsial maupun bersama. Koefisien korelasi pendidikan dan pelatihan dengan kinerja guru $\left(\mathrm{r}_{\mathrm{xy}}\right)$ sebesar 0,556 dengan tingkat hubungan kategori sedang. Hal ini menunjukkan bahwa guru dalam pengembangan kompetensi (pengetahuan, keterampilan, sikap) mempunyai hubungan dengan peningkatan kinerja. Koefisien korelasi kompensasi dengan kinerja guru $\left(\mathrm{r}_{\mathrm{xy}}\right)$ sebesar 0,628 dengan tingkat hubungan kategori kuat. Hal ini menunjukkan bahwa kompensasi yang diterima guru sangat berhubungan yang signifikan dengan kinerja. Demikian juga apabila melihat hasil analisis koefisien korelasi hubungan antara pendidikan dan pelatihan dan kompensasi dengan kinerja guru adalah sebesar 0,654 dengan tingkat hubungan kategori kuat. 
Dari hasil analisis tersebut dapat diutarakan bahwa pendidikan dan pelatihan menunjukkan hubungan kategori baik dengan kinerja guru, oleh karenanya dalam menyelenggarakan pendidikan dan pelatihan sebaiknya didasarkan atas penilaian kebutuhan dari guru sehingga benar-benar efektif, selain itu kompensasi yang memadai yaitu gaji, tujangan dan penghargaan akan semakin meningkatkat kinerja seorang guru. Kinerja guru yang dimaksud adalah kinerja guru yang menyangkut kompetensi yang dimiliki yaitu meliputi kemampuan merencanakan program belajar mengajar, kemampuan melaksanakan proses belajar mengajar, pelaksanaan evaluasi pembelajaran dalam rangka pemenuhan kebutuhan akan administrasi sekolah.

\section{PENUTP}

Berdasarkan hasil penelitian dapat diambil kesimpulan Diklat secara parsial memiliki hubungan positif dengan kinerja guru Sekolah Dasar Negeri di Kota Solok dengan koefisien korelasi 0,556. Kompensasi secara parsial memiliki hubungan positif dengan kinerja guru SD Negeri di Kota Solok dengan koefisien korelasi 0, 628. Diklat dan kompensasi secara simultan memiliki hubungan positif dengan kinerja guru Sekolah Dasar Negeri di Kota Solok dengan koefesien korelasi 0,654. Artinya hubungan antara Diklat dan Kompensasi dengan peningkatan kinerja guru dengan kategori kuat.

\section{KEPUSTAKAANACUAN}

Azwar, S. (2009). Penyusunan Skala Psikologi. Yogyakarta: Pustaka Belajar.
Departemen Agama R. I. (2008). Teknik Pengukuran Kinerja di Lingkungan Departemen Agama, Sek. Jend. Biro Ortala.

Dharma, A. (2000). Mengangkat Citra dan Martabat Guru, Yogyakarta: Adicita Karyanusa.

Handoko, T. H. (2003). Manajemen Sumber Daya Manusia, Jakarta: Salemba Empat.

Hasibuan, M. S.P. (2007). Manajemen Sumber Daya Manusia, Jakarta: Bumi Aksara.

Kadarisman, M. (2012). Manajemen Kompensasi, Jakarta: PT. RajaGrafindo Persada

Lembaga Administrasi Negara RI,(2009) Pendidikan dan Pelatiban Jabatan Pegawai Negeri Sipil, Biro Hukum dan Organisasi, Biro Perencanaan, Organisasi dan Kerjasama, Jakarata: LAN.

Mangkunegara, A.P. (2005). Manajemen Sumber Daya Manusia Perusabaan, Bandung: Remaja Rosdakarya.

Manullang, (1994). Pengembangan Pegawai, Medan: Ghalia Indonesia.

Moehariono, (2009). Pengukuran Kinerja Berbasis Kompetensi, Jakarta: Ghalia Indonesia.

Mondy R.W. (2008) Manajemen Sumber Daya Manusia Untuk Perusahaan, Jakarta: Rajawali Pers.

Muhyi, E. S. (2011). Kepemimpinan Pendidikan Transpormasional, Jakarta: Media Press.

Mukhlisoh N. (2008). Pengaruh Pendidikan dan Pelatiban, Kompensasi dan Kepuasan Kerja Guru terhadap Kinerja Guru, Semarang: UNNES.

Mulyasa, E. (2008). Menjadi Kepala Sekolah Profesional, Bandung: Remaja Rosdakarya. 
Notoatmodjo, S. (2003). Pengembangan Sumber Daya Manusia, Jakarta: Rineka Cipta.

Ranupandojo, H. dan Husnan, S. (1997). Manajemen Personalia, Yogyakarta: BPFE.

Rivai, V. (2005). Performance Appraisal, Jakarta: PT Raja Grafindo.

Rivai, V. dan Jauvani, E. (2010). Manajemen Sumber Daya Manusia untuk Perusahaan, Jakarta: PT Raja Grafindo Persada.

Santoso, S. (2016). Menguasai SPSS 22 From Basic To Expert Skills, Jakarta: Elex Media Komputindo.

Sanusi, A. (1991). Studi Pengembangan Model Pendidikan Profesional Tenaga Pendidikan, Jakarta: Depdikbud.

Sastrohadiwiryo, B. S. (2002) Manajemen Tenaga Kerja Indonesia Pendekatan Administratif dan Operasional, Jakarta: Bumi Aksara.

Siagian, S. P. (2008) Manajemen Sumber Daya Manusia, Jakarta: PT Bumi Aksara.

Simamora, H. (1997). Manajemen Sumber Daya Manusia, Jogjakarta: STIE YKPN.
(2007). Sejarah Pertumbuban dan Pembaharuan Pendidikan Islam di Indonesia, Jakarta: Kencana Prenada Media Group.

Subagio A. (1993). Manajemen Training, Jakarta: Balai Pustaka.

Sudjana, (1996). Methode Statistika, Bandung: Tarsito.

Sugiyono, (2013). Metode Penelitian Pendidikan Pendekatan Kuantitatif, Kualitatif, dan R \& $D$, Bandung: Alfabeta. ., (2015). Statistika Untuk Penelitian, Bandung: Alfabeta. , (2015). Metode Penelitian Manajemen, Bandung: Alfabeta

Supardi, (2013). Aplikasi Statistika Dalam Penelitian, Jakarta: Smart.

Supriyanto, A. S. \& Machfudz, M. (2010). Metodologi Riset Manajemen Sumber Daya Manusia. Malang: UIN Maliki Press.

Umar, H. (2002). Proses Penilaian Kinerja Guru, Jakarta: Rineka Cipta.

Wibowo, (2010). Manajemen Kinerja, Jakarta: PT Grafindo Persada. 